\title{
Transgenic Production of Cytokinin Suppresses Bacterially Induced Hypersensitive Response Symptoms and Increases Antioxidative Enzyme Levels in Nicotiana spp.
}

\author{
B. Barna, A. C. Smigocki, and J. C. Baker
}

First author: Plant Protection Institute, Hungarian Academy of Sciences, H-1022 Herman O. 15. Budapest, Hungary; and second and third authors: Molecular Plant Pathology Laboratory, USDA-ARS, Beltsville, MD 20705.

Accepted for publication 15 July 2008.

\begin{abstract}
Barna, B., Smigocki, A. C., and Baker, J. C. 2008. Transgenic production of cytokinin suppresses bacterially induced hypersensitive response symptoms and increases antioxidative enzyme levels in Nicotiana spp. Phytopathology 98:1242-1247.

Responses of cytokinin overproducing transgenic Nicotiana plants to infections with compatible and incompatible Pseudomonas syringae pathovars were compared. Plants used were transformed with the ipt (isopentenyl transferase) gene that catalyzes the synthesis of cytokinin. In cytokinin overproducing lines that carry the ipt gene fused to the CaMV $35 \mathrm{~S}(\mathrm{Nt}+i p t)$, the wound-inducible proteinase inhibitor II $(\mathrm{Ntx}+i p t)$, or the light-inducible Rubisco small subunit protein (Npl+ipt) promoter, development of the hypersensitive response (HR) after infection with incompatible bacteria ( $P$. syringae pv. tomato) was significantly inhibited as compared to the untransformed (Nt) controls. Over a $12 \mathrm{~h}$ period follow-

control. When the compatible $P$. syringae. pv. tabaci was used to infect the ipt transformed lines, slight or no significant differences in necrosis development were observed. Following infection, the titer of $P$. syringae pv. tabaci increased rapidly in both the transgenic and control lines but was higher in $\mathrm{Nt}+i p t$ plants. Leaf superoxide dismutase and catalase enzyme activities were about $60 \%$ higher in ipt leaf extracts than in the controls. This augmented antioxidant capacity likely decreased the amount of $\mathrm{H}_{2} \mathrm{O}_{2}$ that may be associated with the higher tolerance of plants to pathogen-induced necrosis. In addition, the $\mathrm{Nt}+i p t$ lines had a significantly lower molar ratio of free sterols to phospholipids. The more stable membrane lipid composition and the higher antioxidant capacity likely contributed to the suppressed HR symptoms in the cytokinin overproducing $\mathrm{Nt+ipt}$ plants. In conclusion, the overproduction of cytokinins in tobacco appears to suppress the HR symptoms induced by incompatible bacteria.
\end{abstract} ing inoculation, $P$. syrinage pv. tomato populations were slightly reduced in leaves of the cytokinin-overproducing $\mathrm{Nt}$-ipt line compared with the $\mathrm{Nt}$
Additional keywords: antioxidants, membrane lipids, oxidative burst.
One of the earliest reactions of plants to invading pathogens is the rapid accumulation of active oxygen species (AOS). During the hypersensitive response (HR) of plants to challenge by bacteria, two phases of active-oxygen production, an early nonspecific and a late specific, have been described (21). AOS are known to be involved not only in signal transduction or in limiting pathogen ingress $(14,22,23)$, but also in the induction of tissue necrosis $(4,9,13)$. In nonstressed plant tissues, antioxidants are able to neutralize the effect of AOS. On the other hand, stress associated with leaf senescence is suggested to be accompanied by a decrease in the antioxidant capacity and a subsequent increase in the production of AOS (17).

Senescing tobacco leaves have been shown to be more susceptible to the necrotizing fungal pathogens Alternaria alternata (Fr.) Kreissler $(5,31)$ and Botrytis cinerea (Pers.) (5). In addition, older leaves of tobacco are more sensitive to toxins and to cellwall degrading enzymes produced by necrotrophic pathogens, as well as to autolysis of membrane lipids (5) indicating different strategies of necrotrophs and biotrophs. Namely, while biotrophs induce enhanced cytokinin production because they need the living plant cell, necrotrophs destroy plant tissue by toxins and cell-wall degrading enzymes to get nutrients and to develop (11).

Plant senescence is regulated by a coordinated genetic program in which cytokinins play an important role. In senescing leaves, leaf cytokinin levels are reduced, and external applications of

Corresponding author: B. Barna; E-mail address: bbar@nki.hu

doi:10.1094/PHYTO-98-11-1242

(c) 2008 The American Phytopathological Society cytokinins are well-known to delay tissue senescence. Transgenic plants that express the bacterial ipt (isopentenyl transferase) gene that catalyzes the synthesis of cytokinin exhibit delayed senescence $(10,27,28)$ and increased insect and microbial resistance $(29,30,32)$. In this paper, transgenic tobacco plants with constitutive or inducible promoters that overproduce cytokinins are utilized to analyze their response to infections with compatible and incompatible Pseudomonas spp. in order to gain insight into the mechanism of various symptom developments. Changes in activities of antioxidant enzymes and in membrane lipid composition are reported.

\section{MATERIALS AND METHODS}

Plants and pathogens. The following cytokinin overproducing transgenic lines were used in this study: Nt+ipt, Nicotiana tabacum L. cv. Petit Havana SR1 that carries the ipt gene fused to the CaMV 35S promoter (32); Ntx+ipt, N. tabacum L. cv. Xanthinc with the ipt gene fused to the wound-inducible proteinase inhibitor II promoter $(28,30)$; and the $\mathrm{Npl}+i p t, N$. plumbaginifolia Viv. 43A, where the ipt is under the control of light-inducible Rubisco small subunit protein promoter (34). T2 generation of homozygous Ntx-ipt and Npl-ipt plants were grown from seed and used for the experiments. Tobacco seedlings were grown in $10-\mathrm{cm}$ diameter pots for 4 weeks and then transplanted to $25-\mathrm{cm}$ diameter pots. All plants were propagated in the greenhouse at $25 \pm 2{ }^{\circ} \mathrm{C}$ under a $14 \mathrm{~h}$ light period during experiments.

Cultures of $P$. syringae pvs. tomato 44 and tabaci 11528 were obtained from Myron Sasser, Department of Plant Pathology, University of Delaware, Newark, DE. Bacterial cultures were 
stored in sterile water or on silica gel $(21)$ at $0^{\circ} \mathrm{C}$ for long-term storage. Active cultures were maintained on nutrient agar at $30^{\circ} \mathrm{C}$. Cultures were transferred to fresh medium 16 to $24 \mathrm{~h}$ prior to use. Bacteria were washed by centrifugation and resuspended in deionized water. Bacterial concentration was determined turbidimetrically and/or by dilution plating.

Infiltration of leaves and rating of symptoms. One centimeter diameter areas of fully expanded leaves of tobacco in preflowering stage were infiltrated with bacterial suspensions or water as control using 1-ml needle-less syringe as described previously (21). Necrosis development in the infiltrated area was recorded at 24,48 , or $96 \mathrm{~h}$. Rating of symptoms was made by visual observation and based on a scale of 0 to 5 , where $0=$ no visible symptoms, $1=$ only chlorosis, no necrosis, $2=25 \%$ necrosis, $3=50 \%, 4=75 \%$, and $5=100 \%$ necrosis (2).

Bacterial populations in leaf tissue. A $0.85-\mathrm{cm}$ diameter disk from leaf areas previously infiltrated with $4.4 \times 10^{7}$ colony forming unit $(\mathrm{cfu}) / \mathrm{ml}$ bacterial suspension was excised with a cork borer and ground in $1 \mathrm{ml}$ of $0.1 \mathrm{mM} \mathrm{NaCl}$ in $25 \mathrm{mM}$ potassium phosphate buffer, $\mathrm{pH} 7.0$ with a mortar and pestle. The bacterial concentration was determined by dilution plating on nutrient agar plates 2, 6, and $12 \mathrm{~h}$ after inoculation.

Determination of antioxidative enzyme activities. Enzymes were extracted from fresh tissue as previously described (6). Samples $(0.5 \mathrm{~g})$ from fully developed $2 \mathrm{nd}$ and 3rd lower leaves (counting up from the bottom) of $N$. tabacum cv. Petit Havana $\mathrm{Nt}+$ ipt and $\mathrm{Nt}$ control plants were ground in $3 \mathrm{ml}$ of ice-cold $50 \mathrm{mM}$ TRIS buffer ( $\mathrm{pH} 7.8$ ) containing $2 \mathrm{mM} \mathrm{Na} 2$ EDTA and $5 \mathrm{mM}$ dithiothreitol. Polyvinylpolypyrrolidone (PVPP, $75 \mathrm{mg}$ ) was added to the homogenate which was filtered through one layer of muslin and centrifuged at $15,000 \times g$ for $20 \mathrm{~min}$ at $4^{\circ} \mathrm{C}$. Glycerol was added to the supernatants to a final concentration of $10 \%$ (vol/vol). Polyacrylamide electrophoresis (10\% native gel) and specific staining for superoxide dismutase (SOD; EC 1.15.1.1.), peroxidase (POD; EC 1.11.1.7.), and catalase (CAT; EC 1.11.1.6) enzyme activities were carried out as described previously $(1,6)$. For superoxide dismutase (SOD) staining, the polyacrylamide gels were incubated for $20 \mathrm{~min}$ in the dark in a

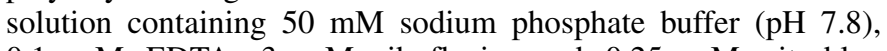
$0.1 \mathrm{mM}$ EDTA, $3 \mathrm{mM}$ riboflavin, and $0.25 \mathrm{mM}$ nitroblue tetrazolium chloride, rinsed with distilled water, placed on a glass sheet, and illuminated for about 10 min under a $200 \mathrm{~W}$ incandescent lamp. The SOD isoenzymes were visualized as achromatic bands against a blue/purple background. For peroxidase (POD) activity, gels were incubated in $100 \mathrm{mM}$ sodium acetate buffer (pH 5.5) containing $1 \mathrm{mM} o$-dianisidine and $0.03 \% \mathrm{H}_{2} \mathrm{O}_{2}$ for 20 min. POD activity appears as orange bands against a clear background. Catalase (CAT) staining was carried out after electrophoresis by incubating the gels in $30 \% \mathrm{H}_{2} \mathrm{O}_{2}$ for $10 \mathrm{~min}$, rinsing with water, staining for $5 \mathrm{~min}$ in $2 \% \mathrm{FeCl}_{3}+2 \% \mathrm{~K}_{3} \mathrm{FeCN}_{6}$ $(1: 1)$ and then rinsing with water again. Relative enzyme activity was determined by densitometry using a Shimadzu model CS930, Kyoto, Japan, scanner, and calculated as total integrated intensity in arbitrary units.

Lipid extraction and determination. Phospholipids (PL), galactolipids (GL), and free sterols (St) were extracted from fully developed 2nd and 3rd lower leaves (counting up from the bottom) of $N$. tabacum cv. Petit Havana Nt+ipt and Nt control plants as described previously (5). Lipids were extracted by homogenizing the leaves in chloroform/methanol (2:1). Extracts were filtered and then washed with $0.1 \% \mathrm{NaCl}$; the organic phase was separated and evaporated to dryness under vacuum. PLs and GLs were separated on precoated thin layer chromatography (TLC) Merck, Germany, Silica Gel 60 plates with chloroform/ acetone/methanol/acetic acid/water (50:20:10:10:5), were identified by co-chromatography of standards (Sigma) and stained with $3 \%$ copper acetate in $5.7 \%(\mathrm{vol} / \mathrm{vol}) \mathrm{H}_{3} \mathrm{PO}_{4}$. Free sterols were separated from lipid extracts with petroleum ether:ether:acetic acid (85:15:1) solvent and stained with $50 \% \mathrm{H}_{2} \mathrm{SO}_{4}$. The position of free sterols on the TLC plate was located by using $\beta$-sitosterol (Sigma) as standard. The amount of PLs, GLs, and free sterols was estimated by densitometry with a Shimadzu model CS-930 scanner, Kyoto, Japan, and calculated as total integrated intensity as compared to commercial standards.

Statistical analysis. At least three independent experiments were conducted in each case. Measurements were carried out in three or four repetitions. Statistical analysis was performed using Student's $t$ test. Differences were considered to be significant at $P<0.05$.

\section{RESULTS}

Effect of the cytokinin biosynthetic gene, ipt, on Pseudomonas-induced necrosis. Lines N. tabacum cv. Petit Havana SR1 either transformed with the ipt gene $(\mathrm{Nt}+i p t)$ or untransformed controls $(\mathrm{Nt})$ were inoculated with varying concentrations of incompatible and compatible pathovars of $P$. syringae. The incompatible pathovar, $P$. syringae pv. tomato, produced a hypersensitive response in the untransformed $\mathrm{Nt}$ plants with almost complete necrosis of the inoculated site at $24 \mathrm{~h}$ at all bacterial concentrations tested (Fig. 1A). However, in the ipt transformed line $(\mathrm{Nt}+i p t)$, the amount of necrosis within the inoculation site after $24 \mathrm{~h}$ increased with the concentration of the bacterial inoculum; inoculum concentrations of $10^{7} \mathrm{cfu} / \mathrm{ml}$ causing only chlorosis while $5 \times 10^{7}$ and $10^{8} \mathrm{cfu} / \mathrm{ml}$ caused nearly complete necrosis. After $48 \mathrm{~h}$, the amount of necrosis in the $\mathrm{Nt}+$ ipt line increased, however at the lower concentrations $\left(1\right.$ to $\left.2 \times 10^{7} \mathrm{cfu} / \mathrm{ml}\right)$ of the inoculum the amount of necrosis was generally less than in the untransformed Nt plants (Fig. 1B).

When the compatible bacterial pathovar $P$. syringae pv. tabaci was used to inoculate the tobacco lines no fast HR was found, visible necrotic (wildfire) symptoms, that are mainly due to the production of tabtoxin by the compatible bacteria, developed at a slower rate in both the Nt+ipt and $\mathrm{Nt}$ control leaves. The incompatible HR is always the consequence of the rapid programmed cell death, while necrosis by $P$. syringae pv. tabaci can develop slowly in tobacco leaves when the bacteria produces enough tabtoxin to develop necrosis. At $24 \mathrm{~h}$, necrosis was found only at higher inoculum concentrations in both $\mathrm{Nt}+i p t$ and $\mathrm{Nt}$ controls (Fig. 1C). After 48 h, necrosis occurred at all concentrations with very little difference between the two tobacco lines (Fig. 1D), indicating that the overproduction of the cytokinins had little effect on the compatible bacterial interaction.

Effect of the cytokinin biosynthetic gene, ipt, on $P$. syringae multiplication. To determine if the reduced symptom development of the $\mathrm{Nt}+i p t$ line inoculated with $P$. syringae pv. tomato was due to reduced multiplication of the bacteria, extracts from infected leaves were titered. Two hours after infiltration of the leaves with $4 \times 10^{7} \mathrm{cfu} / \mathrm{ml} P$. syringae $\mathrm{pv}$. tomato or pv. tabaci, no differences were observed in the concentration of bacteria in $\mathrm{Nt}+$ ipt or control Nt leaves (Fig. 2). By $12 \mathrm{~h}$, the bacterial populations of $P$. syringae pv. tabaci increased greatly in both tobacco lines, but was substantially higher in the $\mathrm{Nt}+$ ipt transformed line. In contrast, populations of the incompatible $P$. syringae pv. tomato decreased in the $\mathrm{Nt}+$ ipt line compared with the $\mathrm{Nt}$ control where the populations remained at a similar level over the $12 \mathrm{~h}$ period following inoculation (Fig. 2).

Antioxidant enzyme levels in $\mathrm{Nt}+i p t$ plants overexpressing cytokinin. Because oxidative enzymes have been closely linked to plant stress and pathogenesis, the activity of SOD, CAT, and POD enzymes were compared in the $\mathrm{Nt}+i p t$ and $\mathrm{Nt}$ tobacco plants. Total activity of SOD and CAT isoenzymes in the transformed $\mathrm{Nt}+$ ipt leaf extracts were 53 and $57 \%$, respectively, higher than that of the Nt leaf extract (Fig. 3). The total POD activity was reduced about $6 \%$ in $\mathrm{Nt}+i p t$ compared with the $\mathrm{Nt}$ control, but this difference was not significant. 
Phospholipid, galactolipid, and free sterol composition of leaves. Overproduction of the cytokinins influenced the leaf membrane polar lipid and sterol composition. $\mathrm{Nt}+i p t$ leaves contained more PLs and GLs but less free sterols as compared to $\mathrm{Nt}$ control leaves (Table 1). As a consequence, the free sterol/ phospholipid ratio in $\mathrm{Nt}+i p t$ plants was approximately half $(0.24)$ that of the control (0.41), a characteristic generally associated with juvenile plant tissues (Table 1).

Disease symptoms on ipt transformed $N$. plumbaginifolia and $N$. tabacum cv. Xanthi plants. Other Nicotiana lines transformed with ipt gene constructs linked to inducible promoters were tested to determine whether they exhibited a similar delay in HR development. When transgenic N. plumbaginifolia (Npl+ipt) plants were inoculated with the incompatible $P$. syringae pv. tomato, necrosis development was delayed and was not as severe as in the untransformed controls (Fig. 4A and B). Inoculation of $\mathrm{Npl+ipt}$ plants resulted in no visible HR symptoms after $24 \mathrm{~h}$
(Fig. 4A) and reduced HR symptoms after 48 h (Fig. 4B), compared with inoculations on Npl control plants. No differences in necrosis development were found when transgenic ipt N. plumbaginifolia and $N$. tabacum plants were inoculated with the compatible $P$. syringae pv. tabaci bacteria and compared with their respective controls (Figs. 4C and 5B). When the Ntx-ipt cytokinin overproducing Xanthi plants were inoculated with $P$. syringae pv. tomato, leaves that exhibited delayed senescence $(24,28)$ also had reduced HR development compared with the Npl plants, but the differences were not significant at $P=0.05$ level (Fig. 5A).

\section{DISCUSSION}

Our earlier results showed that the $\mathrm{Nt}+i p t$ line that carries the ipt gene fused to the CaMV 35S promoter had 130 to $190 \%$ more zeatin riboside and isopentenyl adenosyl type cytokinin content than the N. tabacum L. cv. Petit Havana SR1 control (32) and

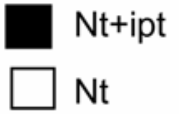

$24 \mathrm{~h}$

\section{P. syringae pv. tomato}
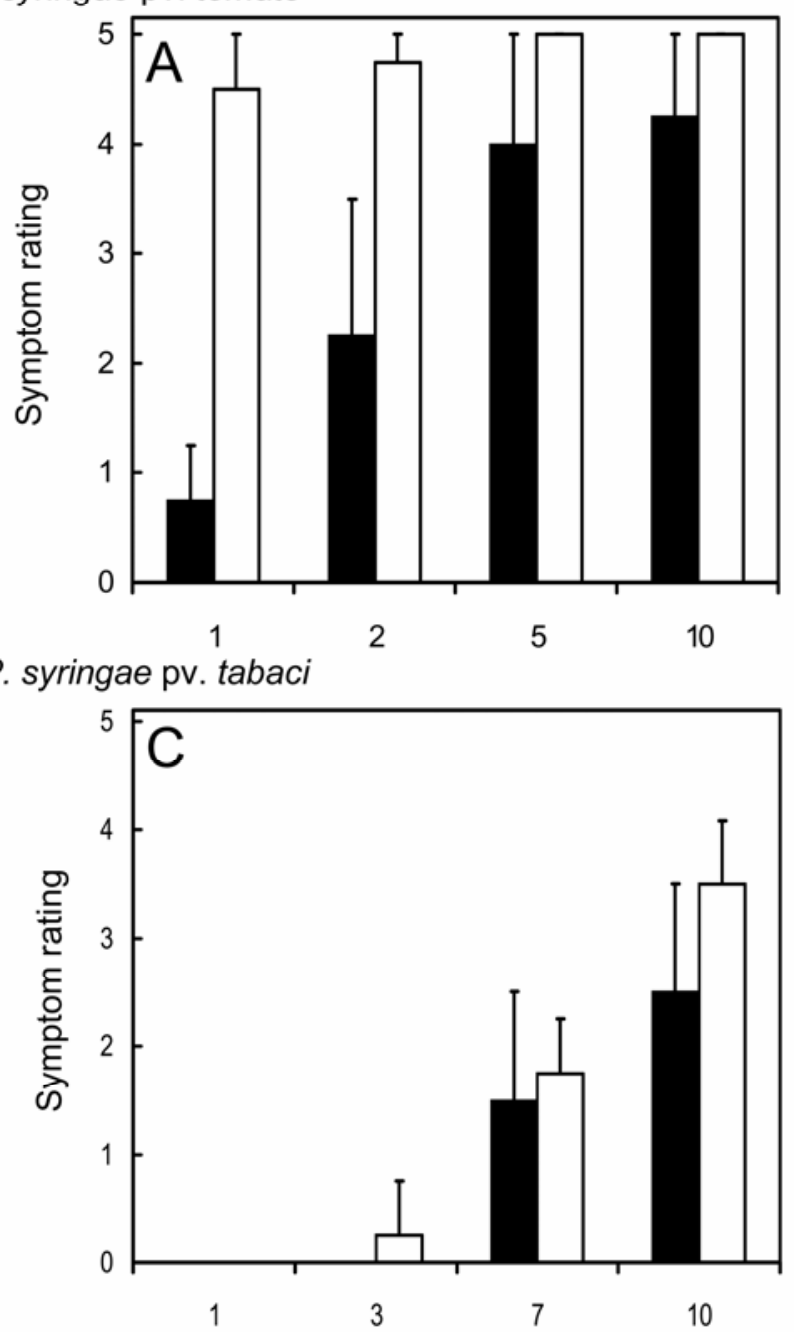

$48 \mathrm{~h}$
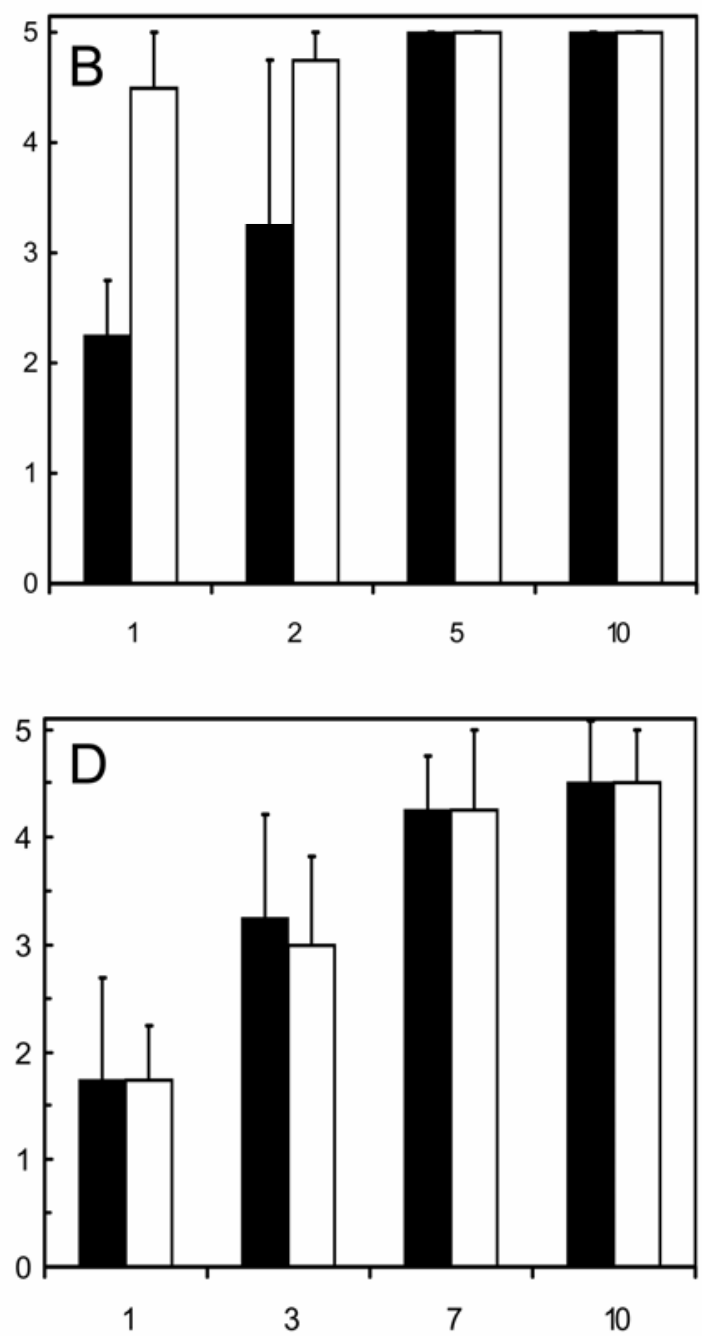

Inoculum concentration ( $\left.\times 10^{7} \mathrm{CFU} / \mathrm{ml}\right)$

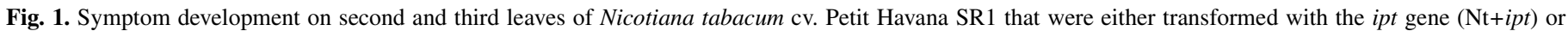

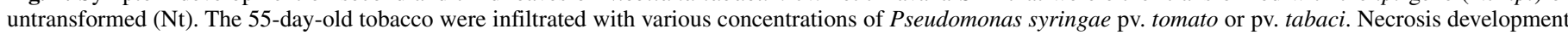

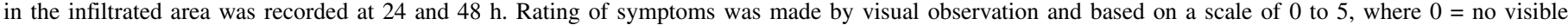

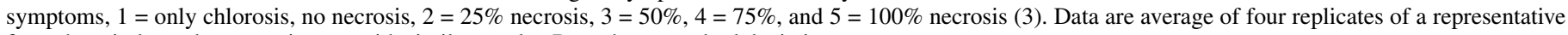
from three independent experiments with similar results. Bars show standard deviations. 
expression of the ipt gene was confirmed by reverse transcriptionpolymerase chain reaction (RT-PCR) (24). The T2 generation of homozygous $\mathrm{Ntx}+i p t, N$. tabacum cv. Xanthi-nc plants with the ipt gene fused to the wound-inducible proteinase inhibitor II promoter had characteristic phenotypes associated with cytokinin overproduction and elevated ipt transcript levels that were woundinducible (28). Given these plants were wounded when they were infected with the Pseudomonas strain, no further wounding (ipt gene induction) was deemed necessary. Similarly, under the relative high light intensity $\left(200 \mu \mathrm{mol} / \mathrm{m}^{2} \mathrm{~s}\right)$ in the greenhouse, the

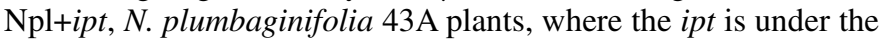
control of light-inducible Rubisco small subunit protein promoter, the zeatin type cytokinins were reported to be two to three times higher than in control plants (34).

The higher cytokinin content of all transgenic lines was also indicated by the slower senescence of the leaves and about a 2 -week delay of flowering as well as by the reduced root development.

Inoculation of $P$. syringae pv. tomato into the cytokininoverproducing $\mathrm{Nt}+i p t$ transgenic line resulted in suppression or delay of HR necrosis, however, in the compatible interaction with
P. syringae pv. tabaci, cytokinin overproduction did not appear to affect symptom development. Bacterial multiplication of $P$. syringae pv. tomato was also delayed during the first $12 \mathrm{~h}$ in transformed leaves, while multiplication of $P$. syringae pv. tabaci was slightly enhanced. Further characterization of these transformed plants demonstrated (i) an increased level of SOD and CAT enzymes, which could enhance the antioxidant capacity, and (ii) a decreased sterol/phospholipid ratio in membrane composition which is associated with juvenile tissue.

The effect of ipt incorporation was tested in other Nicotiana species as well. In $N$. plumbaginifolia, the ipt transformed plants had an even stronger delay in symptom development in response to $P$. syringae pv. tomato, while symptom development was somewhat enhanced in response to $P$. syringae pv. tabaci. In $N$. tabacum cv. Xanthi, the effect of the ipt gene on the symptom development was not as dramatic with either pathogen. There was a slight delay in symptom development with $P$. syringae pv. tomato and slight enhancement with $P$. syringae pv. tabaci. It is noteworthy, that external applications of cytokinins similarly suppressed the bacterially induced hypersensitive reaction (20).

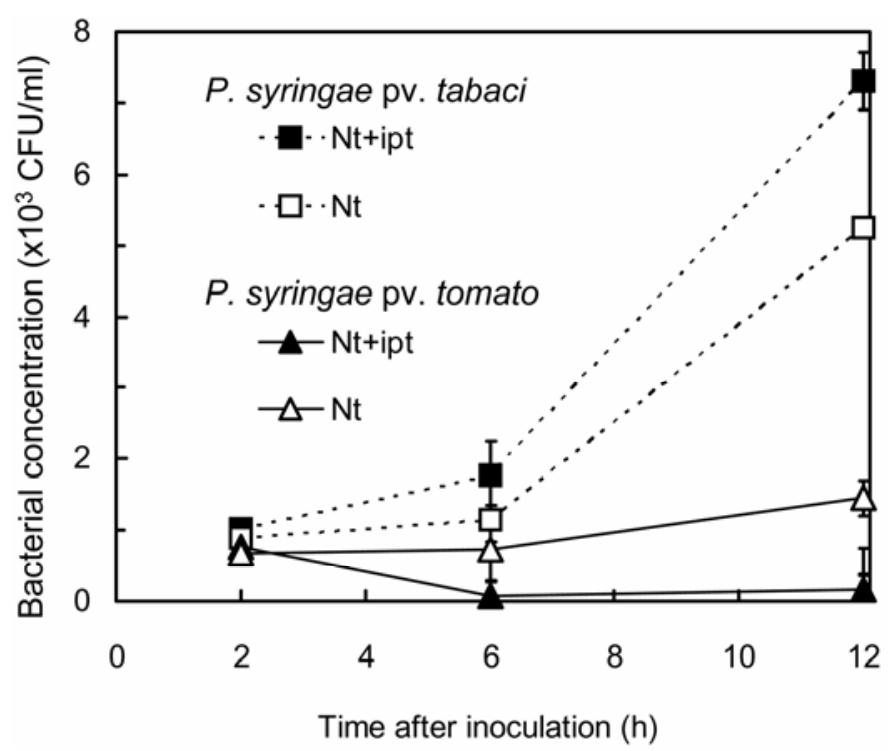

Fig. 2. Multiplication $\left(\times 10^{3}\right.$ colony forming unit $\left.\mathrm{ml}^{-1}\right)$ of Pseudomonas syringae. pv. tomato and $P$. syringae pv. tabaci bacteria in leaves of 55-dayold $\mathrm{Nt}+$ ipt and $\mathrm{Nt}$ tobacco. The bacterial concentration was determined by dilution plating on nutrient agar plates. Data are average of three replicates of a representative from three independent experiments with similar results. Bars show standard deviations.

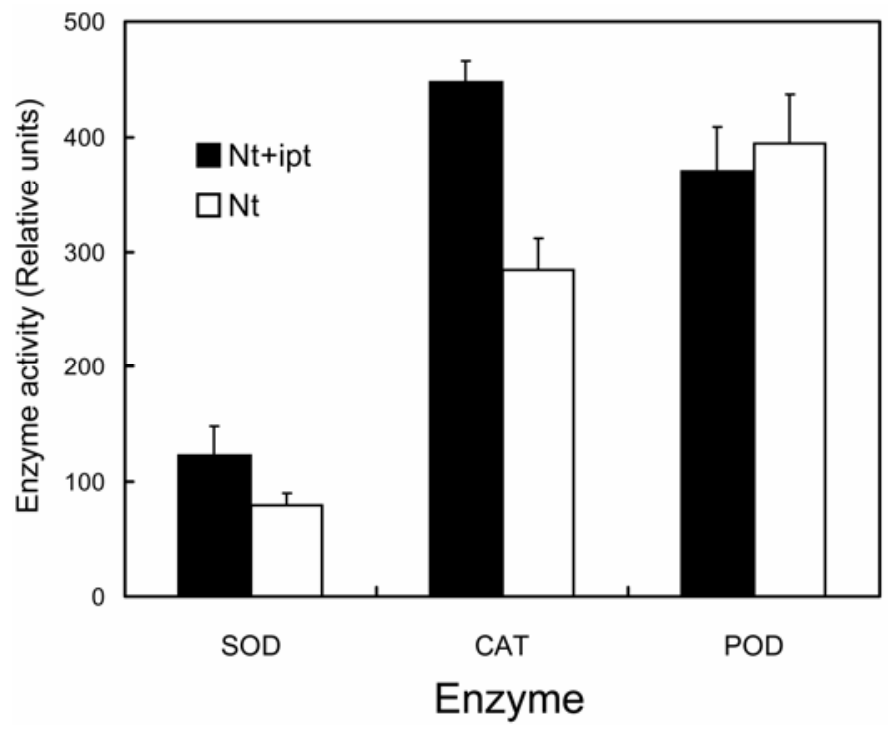

Fig. 3. Activity (relative units) of superoxide dismutase (SOD), catalase (CAT), and peroxidase (POD) enzymes of Nicotiana tabacum cv. Petit Havana SR1 tobacco leaves either transformed with the ipt gene $(\mathrm{Nt}+i p t)$ or untransformed (Nt). Enzyme activities were evaluated by Shimadzu CS-930 scanner. Data are average of three replicates of a representative from three independent experiments with similar results. Bars show standard deviations.

TABLE 1. Comparison of the phospho-(PL) and galactolipid (GL), as well as the free sterol (St) content in transformed (Nt+ipt) or untransformed (Nt) leaves of Nicotiana tabacum cv. Petit Havana SR1 ${ }^{\text {a }}$

\begin{tabular}{lccc}
\hline Lipids $^{\mathrm{b}}$ & Nt (nmole/g fwt) & Nt+ipt (nmole/g fwt) & \% of Nt control \\
\hline PI & $49 \pm 22$ & $64 \pm 8$ & 130.6 \\
PC & $240 \pm 20$ & $300 \pm 106$ & 125.0 \\
PG & $150 \pm 30$ & $198 \pm 42$ & 132.0 \\
PE & $175 \pm 31$ & $210 \pm 30$ & 120.0 \\
Total PL & $614 \pm 59$ & $772 \pm 57$ & 125.7 \\
MGDG & $515 \pm 10$ & $658 \pm 18$ & 127.8 \\
DGDG & $371 \pm 77$ & $500 \pm 32$ & 134.8 \\
Total GL & $886 \pm 87$ & $1158 \pm 50$ & 130.7 \\
St & $251 \pm 10$ & $189 \pm 22$ & 75.3 \\
St/PL & 0.41 & 0.24 &
\end{tabular}

a The second and third leaves of 60-day-old plants were used. Data are the average of four replicates of a representative from three independent experiments with similar results.

${ }^{\mathrm{b}} \mathrm{PI}=$ phosphatidylinositol, $\mathrm{PC}=$ phosphatidylcholine, $\mathrm{PG}=$ phosphatidylglycerol, $\mathrm{PE}=$ phosphatidylethanolamine, MGDG = monogalactosyldiglyceride, DGDG = digalactosyl-diglyceride.

${ }^{\mathrm{c}}$ Least significant differences at $P=0.05$ for total PL, GL, and St are 113, 134, and $31 \mathrm{nmol} \mathrm{g} \mathrm{fwt}^{-1}$, respectively. 
In regards to the effect of the inhibition of plant senescence by cytokinins on multiplication of bacteria in leaf tissue, again, differences were found in compatible and incompatible interactions. Although bacterial multiplication does appear to be reduced in the incompatible reaction, suppression of necrotization (i.e., a suppressed HR response) may actually be associated with de-
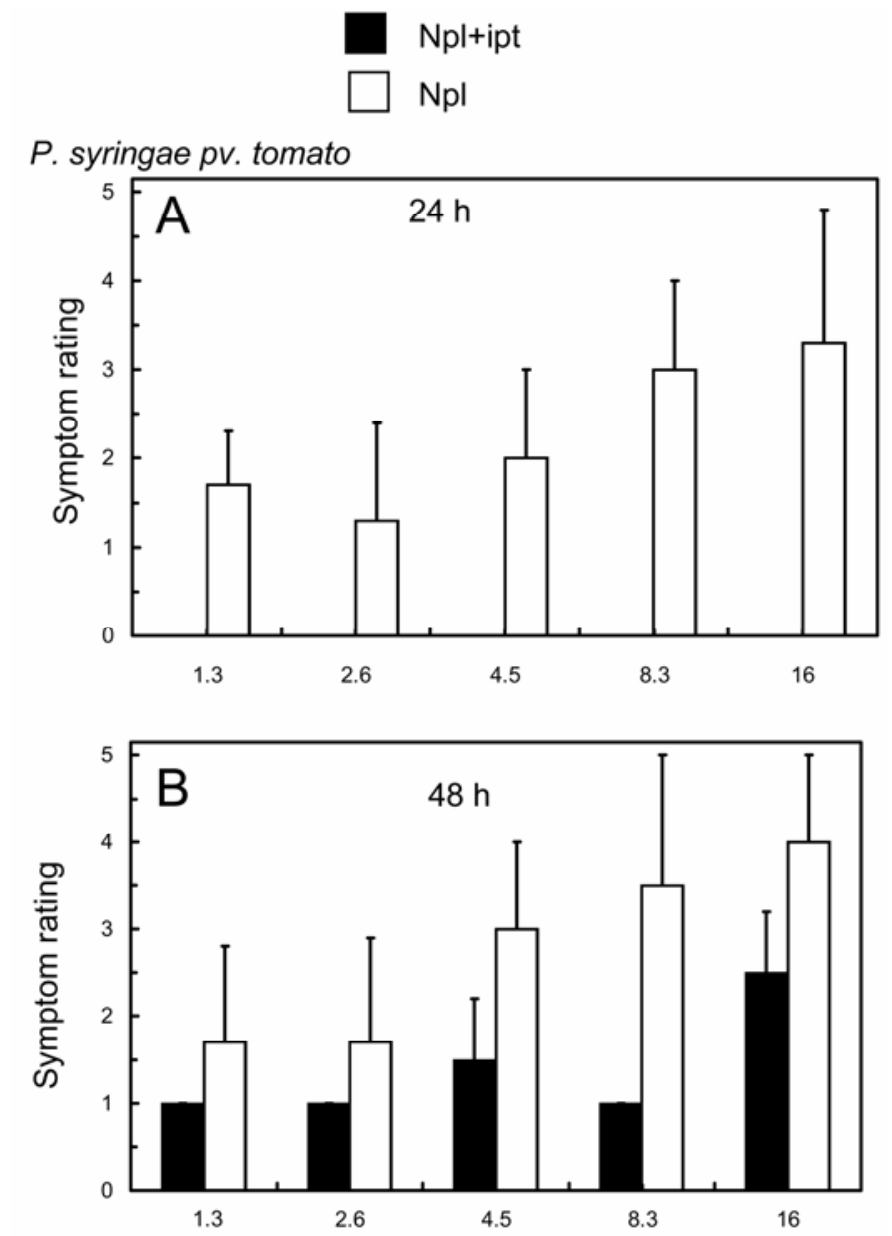

P. syringae pv. tabaci

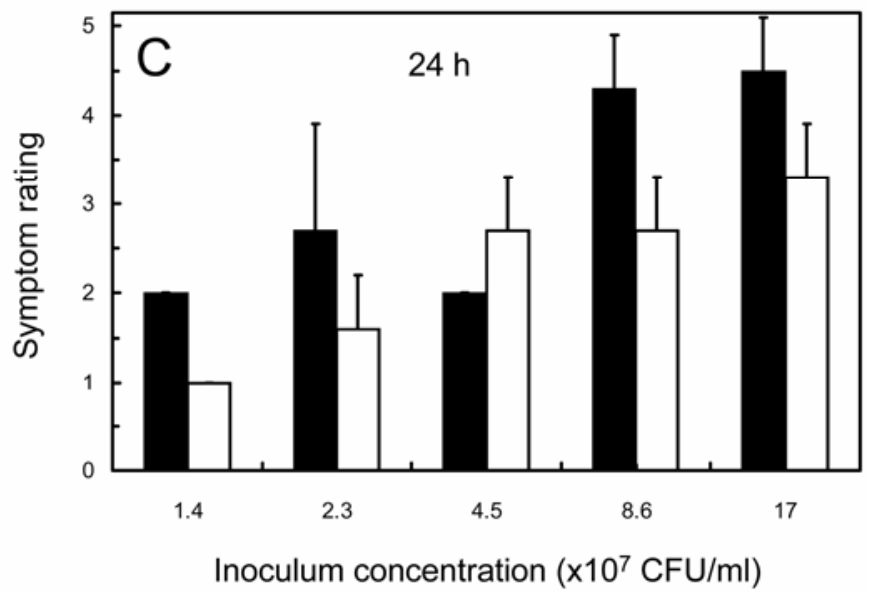

Fig. 4. Symptom development on second and third leaves of Nicotiana plumbaginifolia that were either transformed with the ipt gene $(\mathrm{Npl}+\mathrm{ipt})$ or untransformed $(\mathrm{Npl})$. The 55-day-old tobacco were infiltrated with various concentrations of Pseudomonas syringae pv. tomato or pv. tabaci. Necrosis development in the infiltrated area was recorded at $\mathbf{A}$ and $\mathbf{C}, 24$ and $\mathbf{B}, 48 \mathrm{~h}$. Rating of symptoms was made by visual observation and based on a scale of 0 to 5 , where $0=$ no visible symptoms, $1=$ only chlorosis, no necrosis, $2=25 \%$ necrosis, $3=50 \%, 4=75 \%$, and $5=100 \%$ necrosis (3). Data are the average of four replicates of a representative from three independent experiments with similar results. Bars show standard deviations. creased resistance. This suggests that cytokinin overproduction suppresses both necrotization (Figs. 1A and 4A) and bacterial multiplication in incompatible, but not in compatible interactions, when the bacterial multiplication is rather increased (Fig. 2).

One of the reasons for the elevated tolerance of cytokinin overproducing tissues to bacteria-induced necroses is probably the reduced accumulation of $\mathrm{H}_{2} \mathrm{O}_{2}$, which is likely a consequence of the augmented antioxidant capacity (Fig. 3). In addition, it has to be emphasized that less $\mathrm{H}_{2} \mathrm{O}_{2}$ was detected by 3,3'-diaminobenzidine (DAB) staining in $\mathrm{Nt}+$ ipt than in $\mathrm{Nt}$ leaves and more $\mathrm{H}_{2} \mathrm{O}_{2}$ accumulated in Tobacco necrosis virus infected $\mathrm{Nt}$ than in $\mathrm{Nt}+$ ipt tobacco lines, which was probably due to the spectrophotometrically measured higher antioxidant capacity in cytokinin overproducing tobaccos (24). Senescence of plant tissues was accompanied by elevated $\mathrm{H}_{2} \mathrm{O}_{2}$ production and reduced antioxidant activity $(12,15,16,33)$ and higher antioxidant activity was found in cytokinin overproducing tobacco line $\left(\mathrm{P}_{\mathrm{SAG} 12}\right.$-IPT) with a senescence-specific transgene promoter $(8,10)$.

The other important factor of the higher resistance of tobacco lines with delayed senescence to the bacterially induced hypersensitive reaction is the more stable membrane lipid composition.
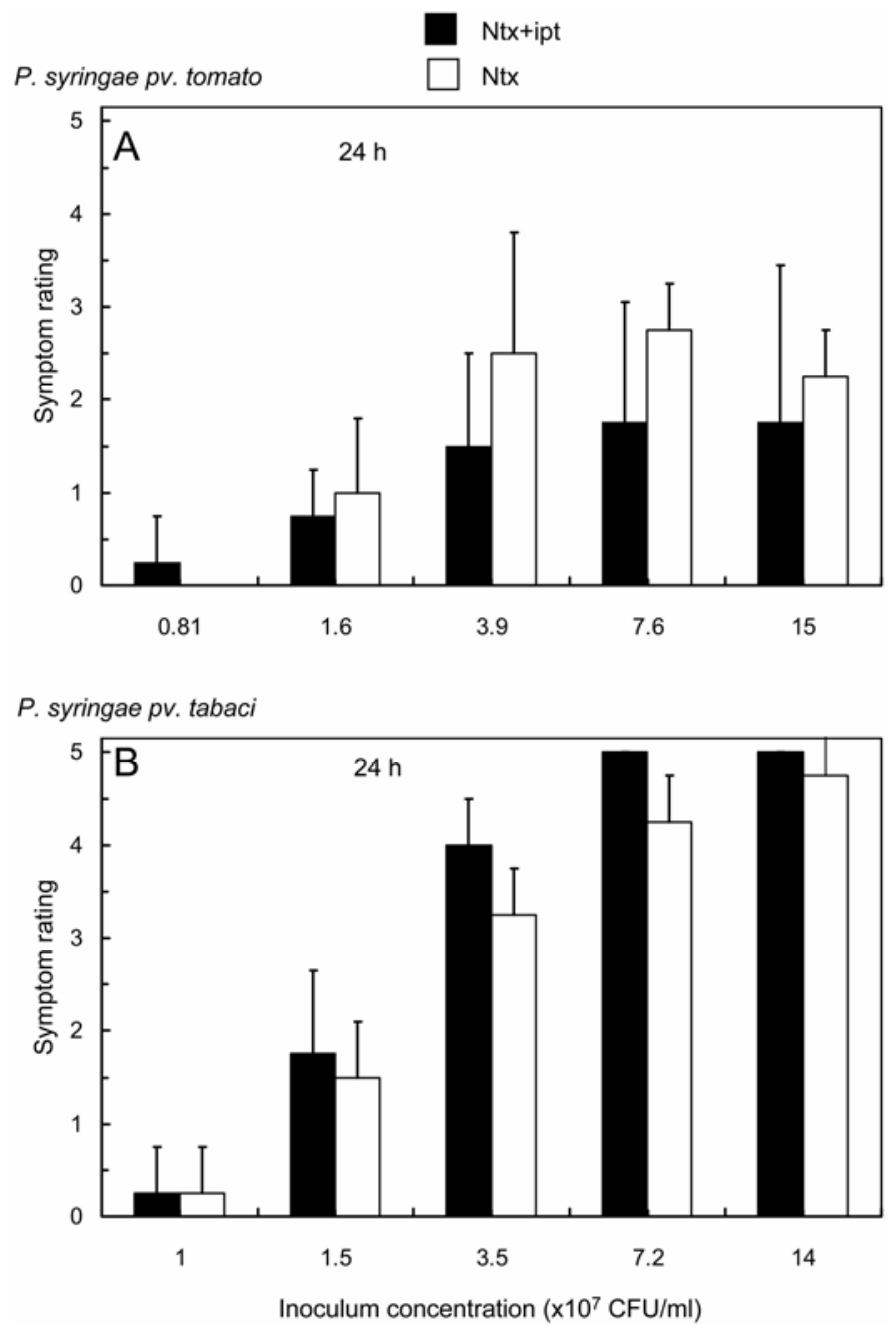

Fig. 5. Symptom development on second and third leaves of Nicotiana tabacum $\mathrm{cv}$. Xanthi that were either transformed with the ipt gene $(\mathrm{Ntx}+i p t)$ or untransformed $(\mathrm{Ntx})$. The 55-day-old tobacco were infiltrated with various concentrations of Pseudomonas syringae A, pv. tomato or B, pv. tabaci. Necrosis development in the infiltrated area was recorded at $24 \mathrm{~h}$. Rating of symptoms was made by visual observation and based on a scale of 0 to 5 , where $0=$ no visible symptoms, $1=$ only chlorosis, no necrosis, $2=25 \%$ necrosis, $3=50 \%, 4=75 \%$, and $5=100 \%$ necrosis (3). Data are the average of four replicates of a representative from three independent experiments with similar results. Bars show standard deviations. 
Significant decrease in molar ratio of free sterols to phospholipids was measured in $\mathrm{Nt}+i p t$ than in $\mathrm{Nt}$ tobacco leaves (Table 1). It has been reported earlier that senescence is associated with the breakdown of membrane phospholipids, which is mainly attributed to phospholipases $(5,7,19)$. A lipid-derived senescence retardant inhibits phospholipase D, the key enzyme involved in degradation of membrane phospholipids during the early stages of plant senescence (25). The significant and complex role of lipids and lipid-modifying enzymes in plant disease resistance was emphasized very recently (26).

In conclusion, the overproduction of cytokinins in plant tissues induced by the expression of the cytokinin biosynthesis gene ipt appears to suppress the HR symptoms induced by incompatible bacteria. The reduced HR is likely due, at least in part, to the higher antioxidant capacity and more stable membrane lipid composition of the ipt transformed tissues. On the other hand, we do not know the role of this type of symptom resistance in the interaction between disease resistance proteins and effectors of bacteria, which is still an open question $(3,18)$.

\section{ACKNOWLEDGMENTS}

The study was supported in part by the Hungarian Scientific Research Fund (OTKA T 48572) and an OECD Research Fellowship awarded to B. Barna. We thank N. Mock and E. Gyalókai for technical assistance.

\section{LITERATURE CITED}

1. Ádám, A. L., Bestwick, C. S., Barna, B., and Mansfield, J. W. 1995. Enzymes regulating the accumulation of active oxygen species during the hypersensitive reaction to Pseudomonas syringae phaseolicola. Planta 196:240-249.

2. Baker, C. J., Atkinson, M. M., Roy, M. A., and Collmer, A. 1986. Inhibition of the hypersensitive response in tobacco by pectate lyase. Physiol. Mol. Plant Pathol. 29:217-225.

3. Baker, C. J., Mock, N. M., Whitaker, B. D., Roberts, D. P., Rice, C. P., Deahl, K. L., Aver'yanov, A. A. 2005. Involvement of acetosyringone in plant-pathogen recognition. Biochem. Bioph. Res. Co. 328:130-136.

4. Baker, C. J., and Orlandi, E. W. 1995. Active oxygen in plant pathogenesis. Annu. Rev. Phytopathol. 33:299-321.

5. Barna, B., and Györgyi, B. 1992. Resistance of young versus old tobacco leaves to necrotrophs, fusaric acid, cell-wall degrading enzymes and autolysis of membrane lipids. Physiol. Mol. Plant Pathol. 40:247-257.

6. Barna, B., and Pogány, M. 2001. Antioxidant enzymes and membrane lipid composition of disease resistant tomato plants regenerated from crown galls. Acta Physiol. Plant. 23:273-277.

7. Borochov, A., Halevy, A. H., and Shinitzky, M. 1982. Senescence and the fluidity of rose petal membranes. Plant Physiol. 69:296-299.

8. Dertinger, U., Schaz, U., and Schulze, E. D. 2003. Age-dependence of the antioxidative system in tobacco with enhanced glutathione reductase activity or senescence-induced production of cytokinins. Physiol. Plant 119:19-29.

9. Elstner, E. F., and Osswald, W. 1994. Mechanism of oxygen activation during plant stress. Pages 131-154 in: Oxygen and Environmental Stress in Plants, 102B. R. M. M. Crawford, G. A. F. Hendry, and B. A. Goodman, eds. The Royal Society of Edinburgh, Edinburgh, UK.

10. Gan, S., and Amasino, R. M. 1997. Making sense of senescence: Molecular genetic regulation and manipulation of leaf senescence. Plant Physiol. 113:313-319.

11. Glazebrook, J. 2005. Contrasting mechanisms of defense against biotrophic and necrotrophic pathogens. Annu. Rev. Phytopathol. 43:205227.

12. Jiménez, A., Hernández, J. A., Pastori, G., del Río, L. A., and Sevilla, F. 1998. Role of the ascorbate-glutathione cycle of mitochondria and peroxisomes in the senescence of pea leaves. Plant Physiol. 118:13271335 .
13. Király, L., and Király, Z. 2006. To die or not to die - Is cell death dispensable for resistance during the plant hypersensitive response? Acta Phytopathol. Hun. 41:11-21.

14. Király, Z., Barna, B., Kecskés, A., and Fodor, J. 2002. Down-regulation of antioxidative capacity in a transgenic tobacco which fails to develop acquired resistance to necrotization caused by TMV. Free Radical Res. 36:981-991.

15. Király, Z., El-Zahaby, H., Galal, A., Abdou, S., Ádám, A., Barna, B., and Klement, Z. 1993. Effect of free radicals on plant pathogenic bacteria and fungi and on some plant diseases. Pages 9-19 in: Oxygen Free Radicals and Scavengers in the Natural Sciences. Gy. Mózsik, I. Emerit, J. Fehér, B. Matkovics, and Á. Vincze, eds. Akadémia Kiadó, Budapest, Hungary.

16. Lacan, D., and Baccou, J. C. 1998. High levels of antioxidant enzymes correlate with delayed senescence in nonnetted muskmelon fruits. Planta 204:377-382.

17. Leshem, Y. 1988. Plant senescence processes and free radicals. Free Radical Biol. Med. 5:39-49.

18. Martin, G. B., Bogdanove, A. J., and Sessa, G. 2003. Understanding the functions of plant disease resistance proteins. Annu. Rev. Plant Biol. 54:23-61.

19. McKersie, B. D., Lepock, J. R., Kruuv, J., and Thompson, J. E. 1978. The effects of cotyledon senescence on the composition and physical properties of membrane lipid. Biochim. Biophys. Acta 508:197-212.

20. Novacky, A. 1972. Suppression of the bacterially induced hypersensitive reaction by cytokinins. Physiol. Plant Pathol. 2:101-104.

21. Orlandi, E. W., Hutcheson, S. W., and Baker, C. J. 1992. Early physiological responses associated with race-specific recognition in soybean leaf tissue and cell suspensions treated with Pseudomonas syringae pv. glycinea. Physiol. Mol. Plant P. 40:173-180.

22. Ouf, M. F., Gazar, A. A., Shehata, Z. A., Abdou, El. S., Király, Z., and Barna, B. 1993. The effect of superoxide anion on germination and infectivity of wheat stem rust (Puccinia graminis Pers. f. sp. tritici Eriks. and Henn.) uredospores. Cereal Res. Commun. 21:31-37.

23. Peng, M., and Kuc, J. 1992. Peroxidase-generated hydrogen peroxide as a source of antifungal activity in vitro and on tobacco leaf disks. Phytopathology 82:696-699.

24. Pogány, M., Koehl, J., Heiser,' I., Elstner, E. F., and Barna, B. 2004. Juvenility of tobacco induced by cytokinin gene introduction decreases susceptibility to Tobacco necrosis virus and confers tolerance to oxidative stress. Physiol. Mol. Plant Pathol. 65:39-47.

25. Ryu, S. B., Karlsson, B. H., Özgen, M., and Palta, J. P. 1997. Inhibition of phospholipase D by lysophosphatidylethanolamine, a lipid-derived senescence retardant. Proc. Natl. Acad. Sci. USA 94:12717-12721.

26. Shah, J. 2005. Lipids, lipases, and lipid-modifying enzymes in plant disease resistance. Annu. Rev. Phytopathol. 43:229-260.

27. Smigocki, A. C. 1991. Cytokinin content and tissue distribution in plants transformed by a reconstructed isopentenyl transferase gene. Plant Mol. Biol. 16:105-115.

28. Smigocki, A. C. 1995. Expression of a wound-inducible cytokinin biosynthesis gene in transgenic tobacco: Correlation of root expression with induction of cytokinin effects. Plant Sci. 109:153-163.

29. Smigocki, A. C., Neal, J. W., Jr., McCanna, I., and Douglass, L. 1993. Cytokinin-mediated insect resistance in Nicotiana plants transformed with the ipt gene. Plant Mol. Biol. 23:325-335.

30. Smigocki, A., and Wilson, D. 2004. Pest and pathogen resistance enhanced by heterologous suppression of a cytochrome P450 gene CYP72A2. Biotechnol. Lett. 26:1809-1814.

31. Stavely, J. R., and Slana, L. J. 1971. Relation of leaf age to the reaction of tobacco to Alternaria alternata. Phytopathology 61:73-78.

32. Székács, A., Hegedus, G., Tóbiás, I., Pogány, M., and Barna, B. 2000. Immunoassays for plant cytokinins as tools for the assessment of environmental stress and disease resistance. Anal. Chim. Acta 421:135-146.

33. Takahama, U., Hirotsu, M., and Takayuki, O. 1999. Age-dependent changes in levels of ascorbic acid and chlorogenic acid, and activities of peroxidase and superoxide dismutase in the apoplast of tobacco leaves: Mechanism of the oxidation of chlorogenic acid in the apoplast. Plant Cell Physiol. 40:716-724.

34. Thomas, J. C., Smigocki, A. C., and Bohnert, H. J. 1995. Light-induced expression of IPT from Agrobacterium tumefaciens results in cytokinin accumulation and somatic stress symptoms in transgenic tobacco. Plant Mol. Biol. 27:225-235. 